\title{
Contaminated urban land: a situational analysis
}

\author{
E. F. de Souza, S. C. Bettine \& M. H. Borges \\ Pontifícia Universidade Católica de Campinas, São Paulo, Brasil
}

\begin{abstract}
In the XXI century, urbanization poses to humankind as the main novelty and as an irreversible phenomenon. Currently, more than half of the world population lives in cities and it is estimated that by 2030 this ratio will reach two thirds. Several surveys indicate a direct relationship between urban growth and pollution, identifying urbanization as one of the major causes of the contamination of soil, groundwater and surface water resources. Soil contaminated by anthropogenic activities has been a global concern because where there is soil exposure to harmful substances there are risks to human health and to the environment. This work presents an analysis and discussion of the existing soil contamination in a densely urbanized and highly industrialized area in southeast Brazil. It was observed that in the last ten years the number of polluted areas has increased linearly and on 74 percent of these more than one type of contaminant has been identified, many of them considered to be carcinogenic to humans. It was concluded that the number of remediation processes in the area is incipient and as a function of complex mixtures of chemical compounds specific remediation techniques will be necessary due to the combined effects of these compounds in the long term.

Keywords: contamination of soils, urban areas, environmental risks.
\end{abstract}

\section{Introduction}

Urbanization is a process resulting from the transformation of a rural economy to a service economy concentrated in urban areas. This is a recent global phenomenon, since the urban population exceeded the rural population in the first decade of this century. Projections presented in UN documents [1] indicate that the urban population is expected to exceed $66 \%$ of the global population as early as 2050, with its growth concentrated in megacities and in developing 
countries. Brazil is an example of this urban growth pattern, with the urban population percentage increasing from $55 \%$ to $84 \%$ between 1970 and 2010 [2]. Researchers like Elga et al. [3] have shown a direct relationship between urban growth and pollution, and identified urbanization as one of the major causes of water resources contamination.

Soil contaminated by anthropogenic activities has become a global issue because where the soil was exposed to harmful substances there are potential risks to human health and environment [4]. Soil functions depend on the balance between its structure and composition, which can be disturbed by pollutants originated from human activities and retained therein such as heavy metals, pesticides, industrial chemicals, and sewer among others [5]. In 2004, the US Environmental Protection Agency (USEPA) estimated that there were 294,000 hazardous waste contaminated sites in the United States [6]. In 2007, the European Environment Agency (EEA) estimated that European Union member states already had 246,000 contaminated soil sites requiring remediation [7]. Soil pollution and contamination directly affects urban population water supplies, especially in the case of the groundwater-dependent urban population, which uses these resources in social infrastructure, agriculture and industry [8].

By the year 2000, it became clear that the traditional ways to deal with soil and groundwater pollution generally do not produce effective solutions, and new approaches are required. In Europe, integrated approaches were induced by the EU Water Framework Directive (WFD) which requires its member states to manage water and groundwater quality on a river basin bases In many situations soil and groundwater contamination affects large areas of land, requiring complex solutions, especially in megacities and brownfields. In such cases, mitigation measures need to be integrated into an overall assessment of the interactions between soil, surface water and groundwater [9].

Rehabilitation and restoration of urban degraded areas should properly revitalize the socioeconomic and biodiversity functions of the region [10], considering the renewal of housing, infrastructure, landscape, water supply, sustainable energy supply and also the costs of such measures.

In this context, this paper presents an analysis of the soil contamination in an urban and highly industrialized area in southeast Brazil.

\section{Methodology}

To carry out the analysis of the soil contamination in the studied region, the data from the file "Contaminated and rehabilitated sites in São Paulo State" published in 2015 by São Paulo Environmental Company (CETESB) [11] were used. The information available on the contaminated areas within the São Paulo portion of the Piracicaba, Capivari and Jundiai rivers basins (PCJ basins) was transferred to a MS Excel ${ }^{\odot}$ spreadsheet categorized with the following categories: county, activity, source, affected environmental compartment, identified contaminants, remediation management, presence of free phase or persistent organic pollutants (POPs), emergency measures and treatment methods. These data were then counted and analysed. 


\section{Situational analysis and discussion}

The PCJ basins correspond to the Water Resources Management Unit number 5 of São Paulo State (UGRHI-5), which is highlighted in Figure 1. Figure 1(a) shows the fraction of the urban population living in UGRHI-5 at 2010; 1(b) displays the number of active companies in 2015, and 1(c) depicts gross domestic product (GDP) per capita in 2012 at the region [12].

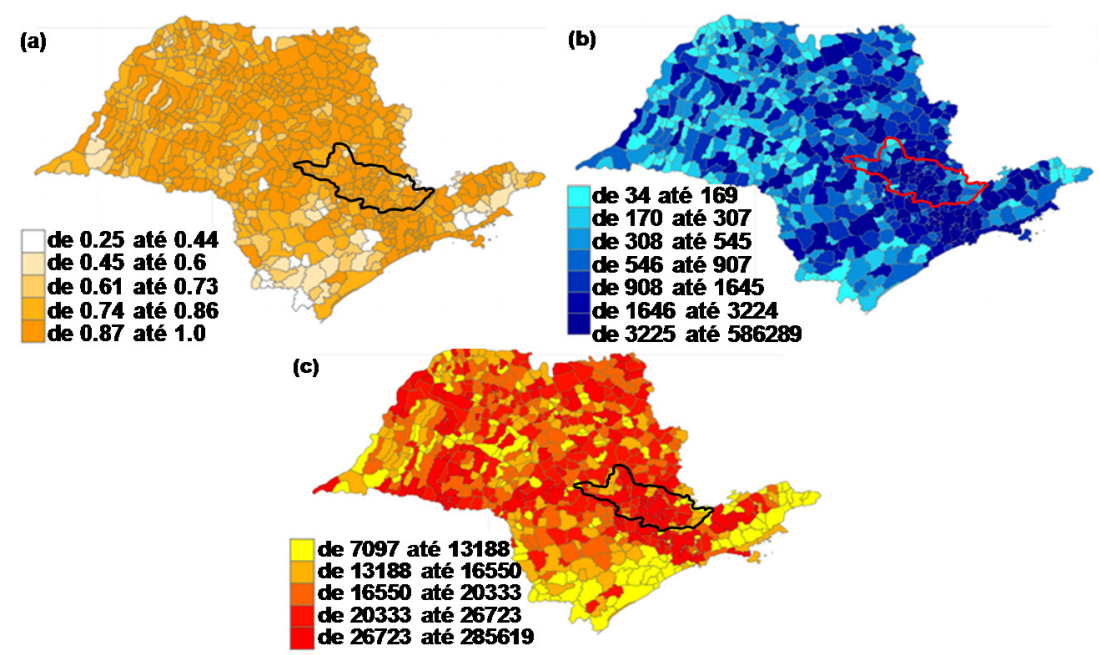

Figure 1: Cartograms of São Paulo State highlighting the studied region.

From the Figure 1 data it is noteworthy that the UGRHI-5 is highly urbanized. It also has a large number of active companies, and a high GDP. Figure 2 presents the number of contaminated sites identified at the analyzed region in 2000-2014.

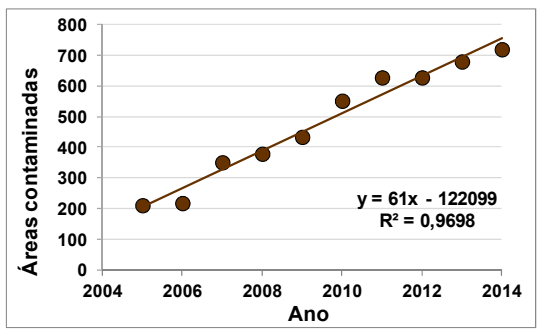

Figure 2: Time evolution of the contaminated sites number at UGRHI-5.

It is observed from Figure 2 that the number of contaminated sites identified at the UGRHI-5 increased almost linearly from 200 in 2005 to 723 in 2014. These UGRHI- 5 contaminated sites are now located in 50 counties as Table 1 shows. 


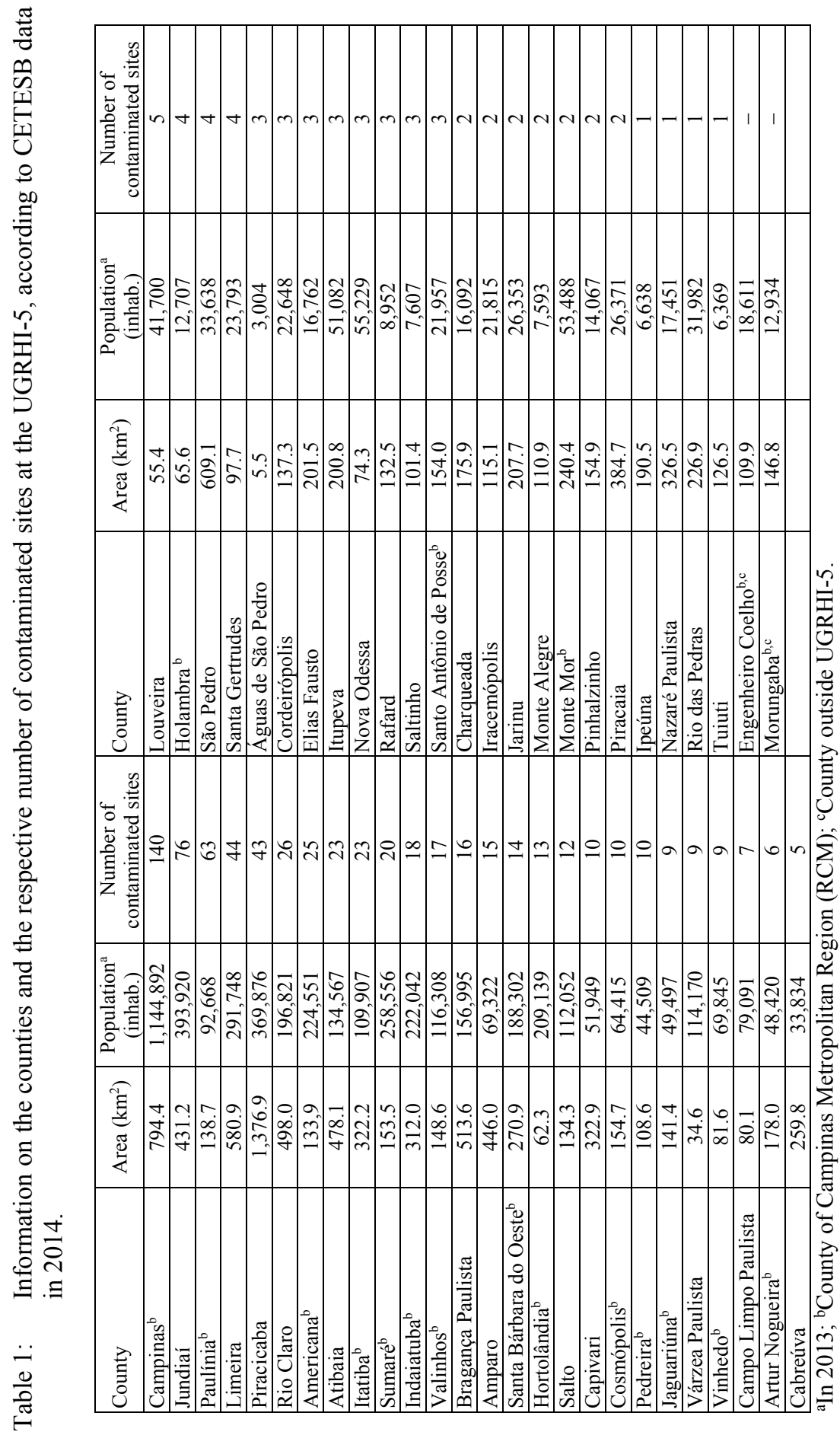


Table 1 data shows a direct relationship between the population and the number of contaminated sites identified at the UGRHI-5. Corroborating the thesis presented by researchers mentioned above, Campinas that has the highest number of contaminated sites (140) also has the largest population $\left(1,144,892\right.$ inhab), and the highest demographic density $\left(1,359.60\right.$ inhab $\left./ \mathrm{km}^{2}\right)$ [2].

\subsection{Origin of contamination and contaminated medium at the UGRHI-5}

Figure 3 exhibits the distribution of activities that originated the contaminated sites detected by CETESB at the UGRHI-5 in 2014, and their sources. As can be seen in Figure 3, the majority of the UGRHI-5 contaminated sites were caused by fuel stations, the main source of contamination corresponding to the fuel storage tanks.
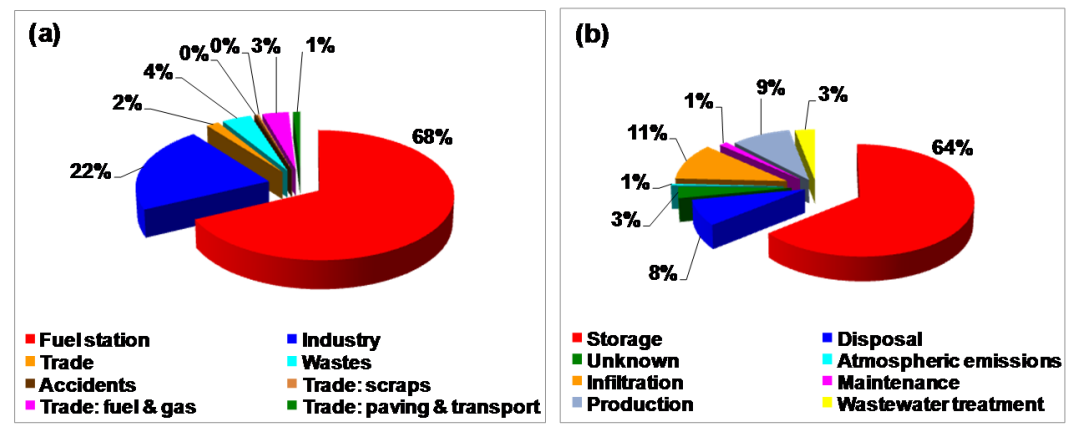

Figure 3: (a) Activity that originated the contaminated areas, and (b) source of contamination at the UGRHI-5.

According to CETESB 2014 data, 97\% of the contaminated sites at the UGRHI-5 have impacts on groundwater, subsoil and topsoil (Table 2). The remaining $2.9 \%$ of the contaminated sites at the UGHRI-5 present extensive contamination that impacts more than three environmental compartment simultaneously, for example, ground surface, surface water and groundwater and sediments (four contaminated media) or even topsoil, subsoil, surface water and groundwater, sediments and biota (six contaminated media).

Table 2: Affected environmental compartment of the UGRHI-5 contaminated sites.

\begin{tabular}{|l|c|c|}
\hline Environmental compartment & Number of sites with contamination & Percentage of total \\
\hline Groundwater & 281 & 39.1 \\
\hline Subsoil and groundwater & 255 & 35.5 \\
\hline Topsoil, subsoil and groundwater & 64 & 8.9 \\
\hline Topsoil and groundwater & 49 & 6.8 \\
\hline Subsoil & 28 & 3.9 \\
\hline Topsoil & 14 & 1.9 \\
\hline Subsoil and topsoil & 6 & 0.8 \\
\hline \multicolumn{1}{|c|}{ TOTAL } & 697 & 97.1 \\
\hline
\end{tabular}




\subsection{Characterization of the contaminations identified at UGRHI-5}

Also according to CETESB 2014, a free phase of contaminant was observed in $26 \%$ of the UGRHI-5 contaminated sites, but in only $1 \%$ of them the presence of persistent organic pollutants (POPs) was detected. $73 \%$ of the contaminated sites at the UGRHI-5 present only organic compounds, and in $11 \%$ only inorganic compounds were found (Table 3 ). Another $11 \%$ of the contaminated sites have the simultaneous presence of organic and inorganic compounds (Table 4).

Table 3: Contaminants detected in the contaminated sites at the UGRHI-5.

\begin{tabular}{|l|l|c|c|}
\hline Class & \multicolumn{1}{|c|}{ Contaminants } & Number of sites & Percentage of total \\
\hline \multirow{5}{*}{} & Automotive fuels, aromatic solvents & 173 & 24.1 \\
\cline { 2 - 4 } & Automotive fuels, aromatic solvents, PAHs & 128 & 17.8 \\
\cline { 2 - 4 } & Aromatic solvents & 76 & 10.6 \\
\cline { 2 - 4 } & Automotive fuels & 51 & 7.1 \\
\cline { 2 - 4 } & Aromatic solvents, PAHs & 41 & 5.7 \\
\cline { 2 - 4 } & Automotive fuels, PAHs & 24 & 3.3 \\
\cline { 2 - 4 } & PAHs & 11 & 1.5 \\
\cline { 2 - 4 } & Halogenated solvents & 8 & 1.1 \\
\cline { 2 - 4 } & Automotive fuels, aromatic solvents, PAHs, & 5 & 0.7 \\
\cline { 2 - 4 } & THP & 5 & 0.7 \\
\cline { 2 - 4 } & Aromatic solvents and THP & 3 & 0.4 \\
\cline { 2 - 4 } & Halogenated and aromatic solvents, TPH, other & 525 & 73.0 \\
\cline { 2 - 4 } & TOTAL & 57 & 7.9 \\
\hline \multirow{5}{*}{ Inorganic } & 5 & 0.7 \\
\cline { 2 - 4 } & Metals & 9 & 0.7 \\
\cline { 2 - 4 } & Metals, other & 5 & 0.1 \\
\cline { 2 - 4 } & Metals, other inorganic & 1 & 0.1 \\
\cline { 2 - 4 } & Metals, inorganic, other & 78 & 10.8 \\
\cline { 2 - 4 } & Other inorganic & 5 & \\
\cline { 2 - 4 } & Other inorganic, other & & \\
\cline { 2 - 4 } & TOTAL & 5 & \\
\hline
\end{tabular}

Table 4: Mixtures of contaminants at the UGRHI-5 contaminated sites.

\begin{tabular}{|l|c|c|}
\hline Contaminants & Number of sites & Percentage of total \\
\hline Metals, halogenated solvents & 12 & 1.7 \\
\hline Metals, aromatic solvents & 8 & 1.1 \\
\hline Metals, THP & 6 & 0.8 \\
\hline Metals, aromatic and halogenated solvents & 5 & 0.7 \\
\hline Metals, phenols & 3 & 0.4 \\
\hline Metals, automotive fuels, aromatics, PAHs, TPH & 3 & 0.4 \\
\hline Metals, methane & 2 & 0.3 \\
\hline Metals, PAHs & 2 & 0.3 \\
\hline Metals, phenols, other & 2 & 0.3 \\
\hline Metals, aromatics and halogenated solvents, PAHs & 2 & 0.3 \\
\hline Metals, aromatic, halogenated solvents, PCBs, phenols & 2 & 0.3 \\
\hline Metals, inorganic, radionuclides, microbiological & 1 & 0.1 \\
\hline Metals, inorganic, aromatic solvents, PAHs, other phenols & 1 & 0.1 \\
\hline Metals, inorganic, solvents, halogenated phenols, PCBs & 1 & 0.1 \\
\hline Metals, halogenated and aromatic solvents, microbiological & 1 & 0.1 \\
\hline Metals, aromatic and halogenated solvents, phenols, TPH & 1 & 0.1 \\
\hline Metals, halogenated aromatic solvents, PAHs, phenols & 1 & 0.1 \\
\hline TOTAL & 53 & 7.4 \\
\hline
\end{tabular}


Table 3 shows that different chemical compounds have been identified even at sites in which only organic contaminants or only inorganic contaminants were detected. Beyond that the complexity of the environmental problem in the studied area can be seen in Table 4, where the sites with complex mixtures of organic and inorganic contaminants are presented.

\subsection{Remediation of the UGRHI-5 contaminated sites}

According to CETESB 2014, no emergency measure was adopted in $70 \%$ of the UGRHI-5 contaminated sites, and only one emergency measure was adopted in $20 \%$ of the sites. However, in some contaminated sites it has been necessary to adopt a set of different emergency measures (Table 5).

Table 5: Number of contaminated sites at UGRHI-5 in which were adopted multiple emergency measures.

\begin{tabular}{|l|c|}
\hline \multicolumn{1}{|c|}{ Multiple emergency measures } & Sites \\
\hline Isolation, environmental monitoring, material removal, interdiction of supply wells & 2 \\
\hline Isolation, environmental monitoring, material removal, prohibition of excavation & 1 \\
\hline Isolation, explosive rate monitoring, environmental monitoring, prohibition of excavation & 1 \\
\hline Isolation, monitoring the explosive index, material removal & 1 \\
\hline $\begin{array}{l}\text { Isolation, ventilation/exhaustion of confined spaces, environmental monitoring, explosive } \\
\text { index monitoring, material removal }\end{array}$ & 1 \\
\hline Ventilation /exhaustion of confined spaces, material removal, prohibition of excavation & 1 \\
\hline
\end{tabular}

In $2014,56.3 \%$ of the UGRHI-5 contaminated sites were in remediation process, were being monitored or declared rehabilitated for use. The other $43.7 \%$ of the contaminated sites were classified as contaminated under investigation, contaminated with confirmed risk or with a reuse process.

Also according to CETESB 2014 data, 332 (45.9\%) contaminated sites had no information about remediation, $46(6.3 \%)$ sites appeared as without remediation measures and in $345(47.7 \%)$ sites were being used one or more remediation methods. The treatment methods used in the 345 UGRHI-5 contaminated sites in which the remediation has taken place during 2014 are shown in Figure 4.

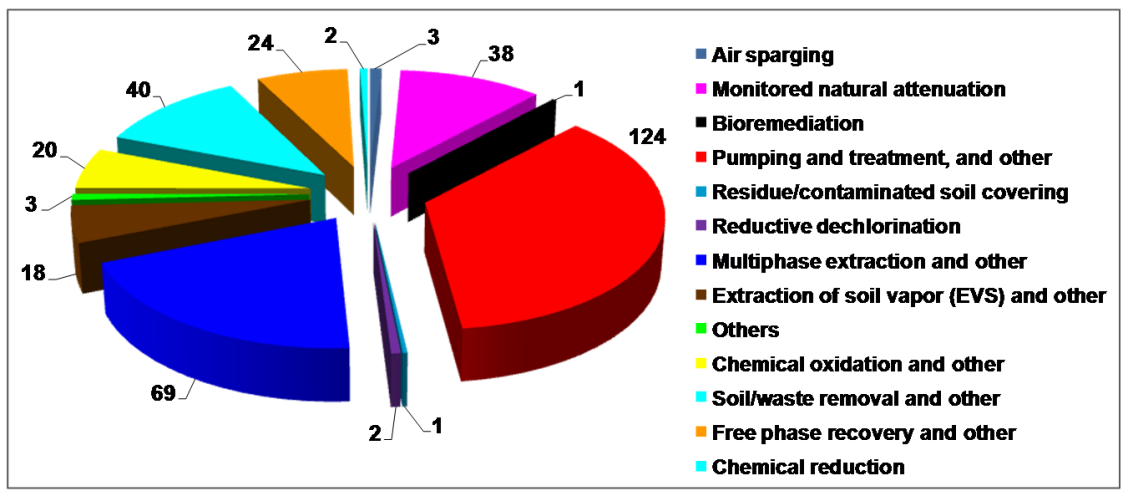

Figure 4: Remediation methods used in the UGRHI-5 contaminated sites. 
At $30.7 \%$ of those 345 contaminated sites is being used more than one remediation method simultaneously. This result reflects the variety and mixtures of chemical compounds present in the UGRHI-5 contaminated sites as presented in Tables 4 and 5.

\subsection{Organic contaminants identified at UGRHI-5}

The contamination of soil and groundwater has been identified in more than five (5) millions sites around the world, with $67 \%$ of them contaminated by organic compounds [13], and the same is observed at the UGHRI-5 contaminated sites. Petroleum products, such as aliphatic hydrocarbons or total petroleum hydrocarbons (TPHs) are components of gasoline, kerosene and lubricants. Aromatic hydrocarbons such as benzene, toluene and xylenes (BTX) are also used as solvents, and in fuels production. The BTX are classified as carcinogenic, flammable, toxic and depressants of the central nervous system, and may cause from headaches and nausea to serious diseases [14]. Brazilian ethanol mainly obtained by sugarcane fermentation increases the solubility and mobility of hydrocarbons such as BTEX, and hinder their natural biodegradation [15].

Polycyclic aromatic compounds (PAH) are persistent organic pollutants in the environment. PAHs are released from various natural and anthropogenic sources, and have multiple benzene aromatic rings giving them low water solubility. These compounds have carcinogenic potential, and may cause damages to bone marrow blood cells and to the nervous system [16].

Polychlorinated biphenyls (PCBs) are synthetic chlorinated hydrocarbon compounds commercially known as Ascarel ${ }^{\circledR}$ that were produced since 1929 in Brazil. Because of their high thermal and chemical stabilities and low vapour pressure at room temperature, PCBs were widely used in electrical capacitors, electrical transformers, vacuum pumps, gas transmission turbines, hydraulic fluids, heat transfer systems, surface coatings, printing inks, adhesives, flame retardants, pesticide extenders, carbon paper [17]. Like many other persistent organic pollutants, even with their production and use prohibited in the country since 1981 they are still detected in the environment.

\subsection{Inorganic contaminants identified at UGRHI-5}

Metals such as calcium $(\mathrm{Ca})$, potassium $(\mathrm{K})$, magnesium $(\mathrm{Mg})$, iron $(\mathrm{Fe})$, zinc $(\mathrm{Zn})$, manganese $(\mathrm{Mn})$ and magnesium $(\mathrm{Mg})$ are extremely important for participating in vital metabolic processes. For example, calcium in the form of hydroxyapatite $\left(\mathrm{Ca}_{5}\left(\mathrm{PO}_{4}\right)_{3} \mathrm{OH}\right)$ is the main factor in bone calcification and tooth enamel. Sodium and potassium contribute to the osmotic balance in cell membranes, and iron is present in the hemoglobin structure, which is responsible for the uptake and transport of oxygen in blood [18]. However, heavy metals like cadmium $(\mathrm{Cd})$, chromium $(\mathrm{Cr})$, mercury $(\mathrm{Hg})$, lead $(\mathrm{Pb})$, copper $(\mathrm{Cu})$, selenium $(\mathrm{Se})$, zinc $(\mathrm{Zn})$ and nickel $(\mathrm{Ni})$ are highly harmful to human health. They are not metabolized by the humans resulting in damage to the respiratory, nervous, digestive, circulatory and renal systems [19]. 
The human exposure to metals can occur from numerous sources, for solid waste may have elevated levels of heavy metals if they contain electronics, cans, bottle caps $\left(\mathrm{Cu}^{2+}, \mathrm{Fe}^{2+}, \mathrm{Sn}^{2+}\right)$; batteries, fluorescent lamps $\left(\mathrm{Hg}^{2+}, \mathrm{Mn}^{2+}, \mathrm{As}^{3+}\right.$, $\left.\mathrm{Sb}^{3+}, \mathrm{Cr}^{3+}\right)$; rechargeable batteries, plastics, alloys, paper, glass, ceramics, $\left(\mathrm{Ni}^{2+}\right.$, $\left.\mathrm{Cd}^{2+}, \mathrm{Pb}^{2+}\right)$, household items, packaging $\left(\mathrm{Al}^{3+}\right)$ and negative radiographs $\left(\mathrm{Ag}^{+}\right)$. Heavy metals can also be found in drugs, insecticides, adhesives, cosmetics. Construction waste have frequent presence of elements such as iron $\left(\mathrm{Fe}^{3+}\right)$, zinc $\left(\mathrm{Zn}^{2+}\right)$, titanium $\left(\mathrm{Ti}^{4+}\right)$, copper $\left(\mathrm{Cu}^{2+}\right)$, arsenic $\left(\mathrm{Ar}^{3+}\right)$ and cadmium $\left(\mathrm{Cd}^{2+}\right)$ [20] Slow dissolution of these metallic wastes deposited at inappropriate places may pollute groundwater, resulting in a possible contamination of the food chain, causing serious diseases to humans.

\subsection{Legislation and the contaminants detected at the UGRHI-5}

The Brazilian federal law (Brazilian Federal Constitution of 1988) establishes the principle that health is a universal right and a duty of the State. The Organic Health Law (Law 8080 of 19 September 1990) provides the conditions for the promotion, protection and recovery of health, as well as the organization and operation of the corresponding services. The Federal Decree 4726 of June 9, 2003, defined the restructuring of the Ministry of Health, with the creation of the Secretariat of Health Surveillance; also defining the ways of protection and recovery of individual and collective health, including that of workers. In 2009, a new structure of the Brazilian Ministry of Health reorganized the technical area to take better care of the population exposed to environmental risks, with regard to air pollution, contaminated sites and chemical hazards. The Surveillance in Health of Populations Exposed to Chemical Contaminants (VIGIPEQD) is guided by the development of health surveillance activities in order to take preventive measures, and to promote the appropriate health care of the population exposed to chemical contaminants. The federal law 9605 (February 17, 1998) also known as Environmental Crimes Law, provided criminal and administrative sanctions to individuals responsible for conduct activities harmful to the environment. In 2009, the National Environmental Council (CONAMA) regulated the contaminated sites management in Brazil through Resolution 420, which established contaminated sites management criteria as well as guiding soil quality values for the presence of chemical substances.

CETESB published in 2001 the Settlement Report of Guiding Values for Soil and Groundwater of São Paulo State, establishing a concentration limit for 37 substances in the soil or groundwater. In December 2005, the CETESB guide was revised and expanded to 84 substances. The updated version of the document was published in February 2014, and defines three guiding values for the chemical compounds concentration limit in soil and in groundwater: quality value $(\mathrm{QV})$, prevention value (PV) and intervention value (IV). These values can be compared with the information on the carcinogenic potential and the data of the exposure limits of each one of these substances (Table 6).

As can be seen in Table 6, some of the organic and inorganic contaminants detected at the UGRHI-5 contaminated sites have been recognized as 
Table 6: Comparison of soil and groundwater concentration limits of São Paulo State with federal standards for drinking water and wastewater for some inorganic and organic chemicals.

\begin{tabular}{|c|c|c|c|c|c|}
\hline Contaminant & $\begin{array}{l}\text { IARC } \\
\text { group }^{\text {a }}\end{array}$ & $\begin{array}{l}\text { CETESB } \\
\text { DD } 045 \\
\mathrm{VP}^{\mathrm{b}} \\
\text { dry soil } \\
(\mathrm{mg} / \mathrm{kg}) \\
\end{array}$ & $\begin{array}{c}\text { CETESB } \\
\text { DD } 045 \\
\text { VI }^{\mathrm{c}} \\
\text { groundwater } \\
(\mathrm{mg} / \mathrm{L})\end{array}$ & $\begin{array}{c}\text { MS } \\
\mathrm{n}^{\mathrm{o}} 2914 \\
\mathrm{VMP}^{\mathrm{d}} \\
(\mathrm{mg} / \mathrm{L})\end{array}$ & $\begin{array}{c}\text { CONAMA } \\
\mathrm{n}^{\mathrm{o}} 357 \\
\mathrm{VMP}^{\mathrm{e}} \\
(\mathrm{mg} / \mathrm{L})\end{array}$ \\
\hline Cadmium & $1 \mathrm{~B}$ & 1.3 & 5 & 0.005 & 0.2 \\
\hline Chrome & $2 \mathrm{~B}$ & 75 & 50 & 0.05 & 0.1 \\
\hline Copper & - & 60 & 2000 & 2 & 1 \\
\hline Lead & 3 & 72 & 10 & 0.01 & 0.5 \\
\hline Manganese & - & - & - & 0.1 & 1 \\
\hline Mercury & 3 & 0.5 & 1 & 0.001 & 0.01 \\
\hline Nickel & $2 \mathrm{~B}$ & 30 & 70 & 0.07 & 2 \\
\hline Zinc & - & 86 & 1800 & 5 & 5 \\
\hline Benzene & 1 & 0.002 & 5 & 5 & 1.2 \\
\hline Benzo[a]pyrene & 1 & - & - & 0.0007 & 0.005 \\
\hline Benzo[a]anthracene & $2 \mathrm{~B}$ & 0.2 & 0.4 & - & 0.00005 \\
\hline Benzo[b]fluoranthene & $2 \mathrm{~B}$ & 0.7 & 0.4 & - & 0.00005 \\
\hline Benzo[k]fluoranthene & $2 \mathrm{~B}$ & 0.8 & 4.1 & - & 0.00005 \\
\hline Carbon tetrachloride & $2 \mathrm{~B}$ & 0.004 & 4 & 4 & 1000 \\
\hline 2-Chlorophenol & 1 & 0.06 & 30 & - & 0.0001 \\
\hline Chlorobenzene & - & 0.3 & 120 & 0.00012 & \\
\hline Chloroform & $2 \mathrm{~B}$ & 0.06 & 300 & - & 0.001 \\
\hline 1,2-Dichlorobenzene & 3 & 0.7 & 1000 & 0.01 & - \\
\hline 1,4-Dichlorobenzene & 2B & 0.1 & 300 & 0,03 & - \\
\hline Dibenzo[a,h]anthracene & 2 & 0.2 & 0.04 & - & 0.05 \\
\hline 1,2-Dichloroethane & $2 \mathrm{~B}$ & 0.001 & 10 & 0.01 & 0.01 \\
\hline 1,1-Dichloroethene & 3 & 0.04 & 30 & 0,03 & 1 \\
\hline 1,2-dichloroethenes & - & $0.01-0.03$ & 50 & 0.05 & 0.0003 \\
\hline 2,4-dichlorophenol & - & 0.03 & 18 & & 0.02 \\
\hline Dichloromethane & $2 \mathrm{~A}$ & 0.02 & 20 & 0.02 & - \\
\hline Di(2-ethylhexyl) phthalate & $2 \mathrm{~B}$ & 1 & 8 & 0,008 & - \\
\hline Ethylbenzene & $2 \mathrm{~B}$ & 0.03 & 300 & 0.0002 & 0.00084 \\
\hline Polychlorinated biphenyls & 1 & 0.0003 & 3.5 & - & 0.001 \\
\hline Surfactants $(\mathrm{LAS})^{\mathrm{f}}$ & - & - & - & 0.5 & 0.5 \\
\hline Styrene & $2 \mathrm{~B}$ & - & - & 0.02 & - \\
\hline Tetrachloroethene & $2 \mathrm{~A}$ & 0.03 & 40 & 0.04 & 0.01 \\
\hline Toluene & 3 & 0.9 & 700 & 0.00017 & 0.0012 \\
\hline Trichlorobenzenes & - & $0.01-0.5$ & 20 & 20 & 20 \\
\hline Trichloroethene & 1 & 0.004 & 20 & 0.02 & 1 \\
\hline Vinyl chloride & 1 & - & - & 0.002 & - \\
\hline Xylenes & 3 & 0.003 & 500 & 0.0003 & 0.0016 \\
\hline
\end{tabular}

${ }^{a}$ International Agency for Research on Cancer; ${ }^{b}$ Permissible Exposure Limits, $\mathrm{mg} / \mathrm{kg}$ of dry soil;

'Threshold Limit Values; ${ }^{\mathrm{d}}$ Prevention Value; ${ }^{\mathrm{e}}$ Intervention Value; ${ }^{\mathrm{f}} \mathrm{Linear}$ alkylbenzene sulfonate.

carcinogenic to humans, and that many others are classified as probably or possibly carcinogenic to humans.

The above data also show that the presence of quantities of the order of parts per million $(\mathrm{mg} / \mathrm{L})$ or parts per billion $(\mu \mathrm{g} / \mathrm{L})$ of these compounds in soil or groundwater are already considered as are prevention or intervention situations, as well as contamination of drinking water and even of wastewater. Moreover, 
the information released by CETESB on UGRHI-5 contaminated sites corresponds to the survey data on point sources of pollution. Data on soil and/or groundwater contamination from nonpoint source pollution, dumping raw sewage directly into watercourses or sewage treatment plant effluents are not yet available. All these sources of pollution have a potential load of metals and contaminants of emerging concern (CECs).

\section{Conclusions}

The analysis of CETESB data here presented support the conclusion that the resident population in the studied area, UGRHI-5 in the southeast state of São Paulo - Brazil, is exposed to potentially dangerous organic and inorganic contaminants.

Despite existing legislation, it is observed that remediation processes are being applied only less than half (47.5\%) of the UGRHI-5 contaminated sites. Thus, the population exposed to these contaminants is at health risk, because in several of those contaminated sites were identified complex mixtures of chemical compounds. Most of the UGRHI-5 detected contamination requires specific remediation techniques that, if not implemented, increase the potential risk to human health because of the chemical compounds combined effects due to long term exposure.

The situation described in this work indicates the urgent need for action both in preventive measures to avoid the number of contaminated sites increase and in research of new efficient remediation methods for soil contamination caused by mixtures of chemicals compounds.

\section{References}

[1] United Nations. World urbanization prospects: The 2014 revision, 2014. http://esa.un.org/unpd/wup/highlights/wup2014-highlights.pdf

[2] Brasil. Instituto Brasileiro de Geografia e Estatística - IBGE. Pesquisa de Informações Básicas Municipais 2013, http://www.snis.gov.br/diag2013/ DiagRS2013_XLS.zip

[3] Elga, S., Jan, B. \& Okke, B., Hydrological modeling of urbanized catchments: A review and future directions. Journal of Hydrology, 529, pp. 62-81, 2015.

[4] Gill, R.T., Harbottle, M.J., Smith, J.W.N. \& Thornton, S.F., Electrokinetic-enhanced bioremediation of organic contaminants: A review of processes and environmental applications. Chemosphere, 107, pp. 31-42, 2014.

[5] Shi, T., Chen, Y., Liu, Y. \& Wu, G., Visible and near-infrared reflectance spectroscopy - An alternative for monitoring soil contamination by heavy metals. Journal of Hazardous Materials, 265, pp. 166-176, 2014.

[6] Luo, Q., Wu, J., Yang, Y., Qian, J. \& Wu, J., Optimal design of groundwater remediation system using a probabilistic multi-objective fast harmony search algorithm under uncertainty. Journal of Hydrology, 519, pp. 3305-331, 2014. 
[7] Söderqvist, T., Brinkhoff, P., Norberg, T., Rosén, L., Back, P.E. \& Norman, J., Cost-benefit analysis as a part of sustainability assessment of remediation alternatives for contaminated land. Journal of Environmental Management, 157, pp. 267-278, 2015.

[8] Fu, F., Dionysiou, D.D. \& Liu, H., The use of zero-valent iron for groundwater remediation and wastewater treatment: A review. Journal of Hazardous Materials, 267, pp. 194-205, 2014.

[9] Petelet-Giraud, E., Negrel, P., Gourcy, L., Schmidt, C. \& Schirmer, M., Geochemical and isotopic constraints on groundwater-surface water interactions in a highly anthropized site. Environmental Pollution, 148(3), pp. 707-717, 2007.

[10] De Sousa, C.A., Turning brownfields into green space in the City of Toronto. Landscape and Urban Planning, 62(4), pp. 181-198, 2003.

[11] Companhia de Tecnologia de Saneamento Ambiental - CETESB. Áreas Contaminadas e Reabilitadas do Estado de São Paulo por URGHI, 2014, http://www.cetesb.sp.gov.br/userfiles/file/areascontaminadas/2014/ ugrhi.pdf

[12] Brasil. Instituto Brasileiro de Geografia e Estatística - IBGE. IBGE Cidades - Web Cart beta 2015, http://www.ibge.gov.br/webcart/ tabelas.php

[13] Biswas, B., Sarkar, B., Rusmin, R. \& Naidu, R., Bioremediation of PAHs and VOCs: Advances in clay mineral-microbial interaction. Environment International, 85, pp. 168-181, 2015.

[14] Martins, L., Impacto à saúde e ao meio ambiente do aumento irregular de solventes na gasolina, 2015, http://bd.camara.gov.br/bd/bitstream/handle/ bdcamara/1027/impacto_saude_juras.pdf?sequence $=4$

[15] Kulkamp, M.S., Kaipper, B.I.A. \& Corseuil, H.X., Influência do etanol na atenuação natural de hidrocarbonetos de petróleo em um aquífero contaminado com uma mistura de diesel e etanol. Resumos do $22^{\circ}$ Congresso Brasileiro de Engenharia Sanitária e Ambiental, ABAS: São Paulo, 2003.

[16] Companhia de Tecnologia de Saneamento Ambiental - CETESB. Significado ambiental e sanitário das variáveis de qualidade das águas e dos sedimentos e metodologias analíticas e de amostragem, 2009, http://www.cetesb.sp.gov.br/userfiles/file/agua/aguas_superficiais/aguasint eriores/variaveis/aguas/variaveis_quimicas/hidrocarbonetos_aromaticos policiclicos.pdf

[17] Penteado, J.C.P \&Vaz, J.M., O legado das bifenilas policloradas (PCBs). Química Nova, 24(3), pp. 390-398, 2001.

[18] Nelson, D.L.M. \& Cox, M., Princípios de Bioquímica de Lehninger, Artmed: Porto Alegre, pp. 505-528, 2014.

[19] Baird, C. Química ambiental. Bookman: Porto Alegre, pp. 403-437, 2011.

[20] Lima, V.F. \& Merçon, F., Metais pesados no Ensino de Química, Química Nova na Escola, 33(4), pp. 199-205, 2011. 